\title{
BIBLIOMETRIC AND BENCHMARK ANALYSIS OF GOLD OPEN ACCESS IN SPAIN: BIG OUTPUT AND LITTLE IMPACT
}

\author{
Análisis bibliométrico y comparativo de la ruta dorada \\ del acceso abierto en España: mucha producción y \\ poco impacto
}

\section{Daniel Torres-Salinas, Nicolás Robinson-García, and Isidro F. Aguillo}
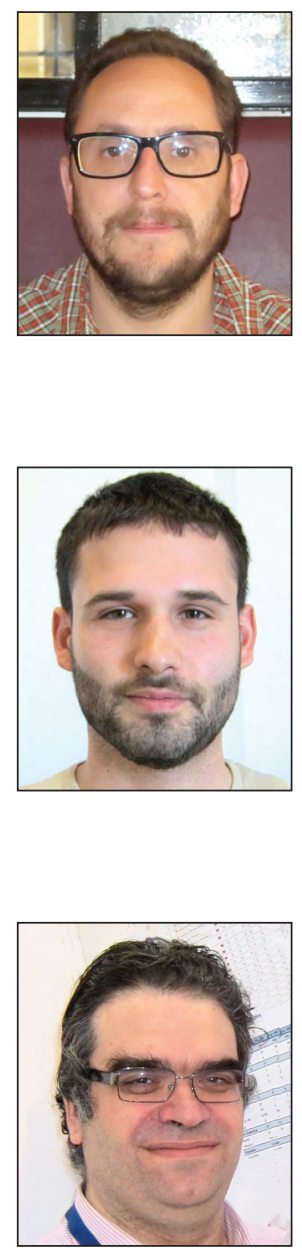

Daniel Torres-Salinas holds a PhD in scientific documentation. He currently works as bibliometrician at the University of Granada and the University of Navarra. He is researcher in EC3 Research Group (Evaluación de la Ciencia y de la Comunicación Científica), CEO of the EC3metrics spin-off and coordinator of the Digital Science Section in Medialab UGR. He is co-author of evaluation tools such as Científicacvn, Rankings I-UGR de Universidades, Clasificación Integrada de Revistas Cientificas (CIRC), Bipublishers, and UGRinvestiga. He teaches courses on scholarly communication, web 2.0 and science, and research services for libraries.

http://orcid.org/0000-0001-8790-3314

Universidad de Navarra y Universidad de Granada (EC3metrics y Medialab UGR) CTTGran Vía, 48. 18010 Granada, Spain torressalinas@gmail.com

Nicolás Robinson-García holds a PhD in social sciences from the University of Granada. He is a postdoctoral researcher in the field of bibliometrics and is interested on research evaluation at the institutional level, the evaluation of monographs, and the study of new data sources for bibliometric analysis. He is currently working at Ingenio (CSIC-UPV) at the Universitat Politècnica de València as a Juan de la Cierva Posdoctoral Research Fellow. http://orcid.org/0000-0002-0585-7359

Ingenio (CSIC-UPV), Universitat Politècnica de València Camino de Vera s/n, 46022 Valencia, España elrobin@ingenio.upv.es

Isidro F. Aguillo is head of the Cybermetrics Laboratory at the Instituto de Políticas y Bienes Públi$\cos$ (IPP) from the Spanish National Research Council (CSIC). He is editor of the journal Cybermetrics, first born-digital journal from CSIC; and of the Ranking Web of Universities, Research Centers, Hospitals, and Repositories. He has published more than 200 papers on cybermetrics, research evaluation, web indicators, and electronic journals. He has a bachelor degree on biology from the Universidad Complutense de Madrid and a masters on information science from Universidad Carlos III de Madrid.

http://orcid.org/0000-0001-8927-4873

CSIC, Instituto de Políticas y Bienes Públicos, Laboratorio de Cibermetría Albasanz, 26-28. 28037 Madrid, Spain isidro.aguillo@cchs.csic.es

\section{Abstract}

This bibliometric study analyzes the research output produced by Spain during the 2005-2014 time period in Open Access (OA) journals indexed in Web of Science. The aim of the paper is to determine if papers published in Open Access journals contribute to the improvement of citation impact and collaboration indicators in Spanish research. The results are shown by scientific areas and compared with 17 European countries. Spain is the second highest ranking European country with gold OA publication output and the fourth highest in Open Access output (9\%). In Spain OA output is especially high in the fields of Arts and Humanities (28\%). Spain's normalized citation impact in Open access (0.72) is lower than the world average and 
that of the main European countries. Finally, we discuss how these results differ from the so-called Open Access citation advantage.

\section{Keywords}

Open Access; Gold road; Web of Science; Análisis bibliométrico; Research impact; International collaboration; Spain; Europe.

\section{Resumen}

Estudio bibliométrico que analiza la contribución de los científicos españoles a las revistas en acceso abierto indexadas en la Web of Science durante 2005-2014. El objetivo es determinar si la publicación en revistas en acceso abierto contribuye a mejorar los indicadores bibliométricos de impacto y colaboración de la ciencia española. Los resultados se presentan por áreas científicas y se comparan con un conjunto de 17 países europeos. Los resultados establecen que España es el segundo país europeo con un mayor porcentaje trabajos en acceso abierto (9\%), especialmente en Arte y Humanidades (28\%). Se establece como la citación normalizada $(0,72)$ de la producción en acceso abierto está por debajo de la media mundial y de los valores de las principales potencias europeas. Finalmente se discute como los resultados entran en contradicción con la denominada ventaja de citación del acceso abierto.

\section{Palabras clave}

Acceso abierto; Ruta dorada; Web of Science; Bibliometric analysis Impacto científico; Colaboración internacional; España; Europa.

Torres-Salinas, Daniel; Robinson-García, Nicolás; Aguillo, Isidro F. (2016). "Bibliometric and benchmark analysis of gold open access in Spain: big output and little impact". El profesional de la información, v. 25, n. 1, pp. 17-24.

http://dx.doi.org/10.3145/epi.2016.ene.03

\section{Introduction}

The Open Access movement has its roots in two different initiatives. First, the proposal led by the physicist Paul Ginsparg (1994) for exchanging pre-prints and the launch of the pioneer repository arXiv. Second, the response of the research community to the so-called 'serial crisis' (Odlyzko, 1995); when the price of journal subscriptions for academic libraries increased in such a substantial way that it threatened the limited budget available for subscriptions, even at rich institutions. Both initiatives led to the achievement of universal access to scientific publications and benefitted greatly from the introduction of the Web and the expansion of electronic publications. For most purposes, the starting point of the Open Access movement took place in 2002 with the publication of the so-called Budapest Open Access Initiative:

http://www.budapestopenaccessinitiative.org/read

One of the leaders of this initiative, Stevan Harnad coined the term green road to refer to the efforts of depositing preand post-prints in an international network of Open Access repositories, reserving the gold road denomination for the Open Access (hereafter OA) journals offering their contents free of charge on the Web (Harnad et al., 2004).

\section{Spain has relatively high research output} in OA journals when compared with the world average

These two alternative venues, green and gold, have expanded in the research community and are promoted by different parties. While some journals have been forced to change their business model, in many cases adopting an APC policy (article processing charges) in order to sup- port the gold road, OA advocates have strongly promoted self-archiving (green road) and the use of institutional and thematic repositories (Harnad, 2007). In this sense, most of the studies analyzing the citation advantage of OA are focused on green OA and not on OA journals (Swan, 2010). The publication of gold OA is full of controversy because of the APC business model imposed by many of these journals, and because of the emergence of predatory journals which have created confusion and alarm in many researchers with regard to OA publishing (Agrawal, 2014; Beall, 2015).

In Spain the two roads, green and gold, have been used since the late 1990s, and are especially popular in the areas of Social Sciences and Humanities (Villalón-Panzano; Aguillo, 1998). In addition, institutional repositories exist in most Spanish universities and research-related organizations (Alonso-Arévalo; Subirats; Martínez-Conde, 2008; Melero et al., 2009). Electronic publication has allowed the emergence of many new titles of periodicals, but after almost two decades not all of them have achieved a relevant impact in their academic communities (Archambault et al., 2014; Björk; Roos; Lauri, 2009). The new Spanish legislation on scientific research promotes self-archiving as well as publishing in OA journals, even when these journals are requesting $A P C$ which is quite common with the most prestigious international OA journals (Björk; Solomon, 2015); however, APC are questioned within Spain and Latin America (Abadal, 2015).

This study focuses on the situation of OA publishing among the Spanish research community, analyzing the impact of such output as well as comparing international collaboration patterns between gold OA papers and the overall production of Spain. It also offers a comparison between the performance of Spain and other European countries. So far, no other study has been found analyzing the gold OA research output of Spanish institutions, although a recent stu- 
dy by Abadal et al. (2015) focused on the journals. Some studies can be found in relation to other countries. For instance, VanLeeuwen, Tatum, and Wouters (2015) analyzed the state of gold OA for The Netherlands, Denmark, and Switzerland concluding that the share of output from OA journals lagged behind when compared with non-OA journals. They also found out that gold OA papers consistently have a lower citation impact and are published in journals with a low impact factor. The present paper also offers a comparison with 17 European countries as well as with the world average, offering the perfect benchmark to compare the status of gold $\mathrm{OA}$ in these countries.

\section{Material and methods}

This paper analyzes the Spanish research output published in gold OA journals indexed in the Web of Science and compares it with the output of other European countries. The study time period is 2005-2014. The dataset used was retrieved from the Thomson Reuters InCites bibliometric suite, a web-based research evaluation tool which aggregates bibliographic data from the Web of Science citation indexes, showcasing indicators of productivity and citation impact of researchers, institutions, and countries. The Web of Science database has recently introduced a filtering option to identify papers published in OA journals (Torres-Salinas; OrduñaMalea, 2014). In order to benchmark the Spanish contribution of gold OA literature with other European countries we focused on three specific aspects of such research: total gold OA output, gold OA impact, and international collaboration in gold OA output. We must note that an institutional full count method has been used to quantify the number of publications. Next, we define the indicators employed as described in InCites:

http://researchanalytics.thomsonreuters.com/m/pdfs/ indicators-handbook.pdf

\section{OA research output}

- OA publications. Total number of papers published in OA journals.

- \% OA publications. Share of papers indexed in OA journals based on the whole research output of a given country.

\section{OA impact}

- Category Normalized Citation Impact for OA and all publications. Citations per paper normalized for subject category, year, and document type. The value of this indicator will be above 1 if its impact is higher than the the world average. If the value is below 1 it is interpreted as below the world average impact.

- \% Documents in top 10\% for OA and all publications. Share of the whole OA output of a given country included within the top $10 \%$ of highly cited papers.

\section{Collaboration}

- \% International collaboration for OA and all publications. Share of papers co-authored by researchers from institutions from two or more countries.

The proportion of Spanish OA papers is $3 \%$ higher than the rest of the world; over a ten year period the difference remains relatively constant

\section{Results}

\subsection{Contribution in OA journals}

During the 2005-2014 period Spain produced a total of 620,709 papers indexed in the Web of Science from which 56,300 were published in OA journals. Around $9 \%$ of its research output was included in OA journals while only $6 \%$ of the world output was published in OA journals (from the total of $20,404,097$ papers produced during the study time period, $1,238,043$ were gold OA papers). As observed in figure 1 , there is a $3 \%$ difference between the OA papers of Spain and the world's output; over a ten year period the difference remains relatively constant.

Figure 2 shows the research output of 17 European countries in relation to the share of output published in $\mathrm{OA}$ journals during the studied time period. Spain is -behind England, France, and Italy- the fourth most productive Eu- 


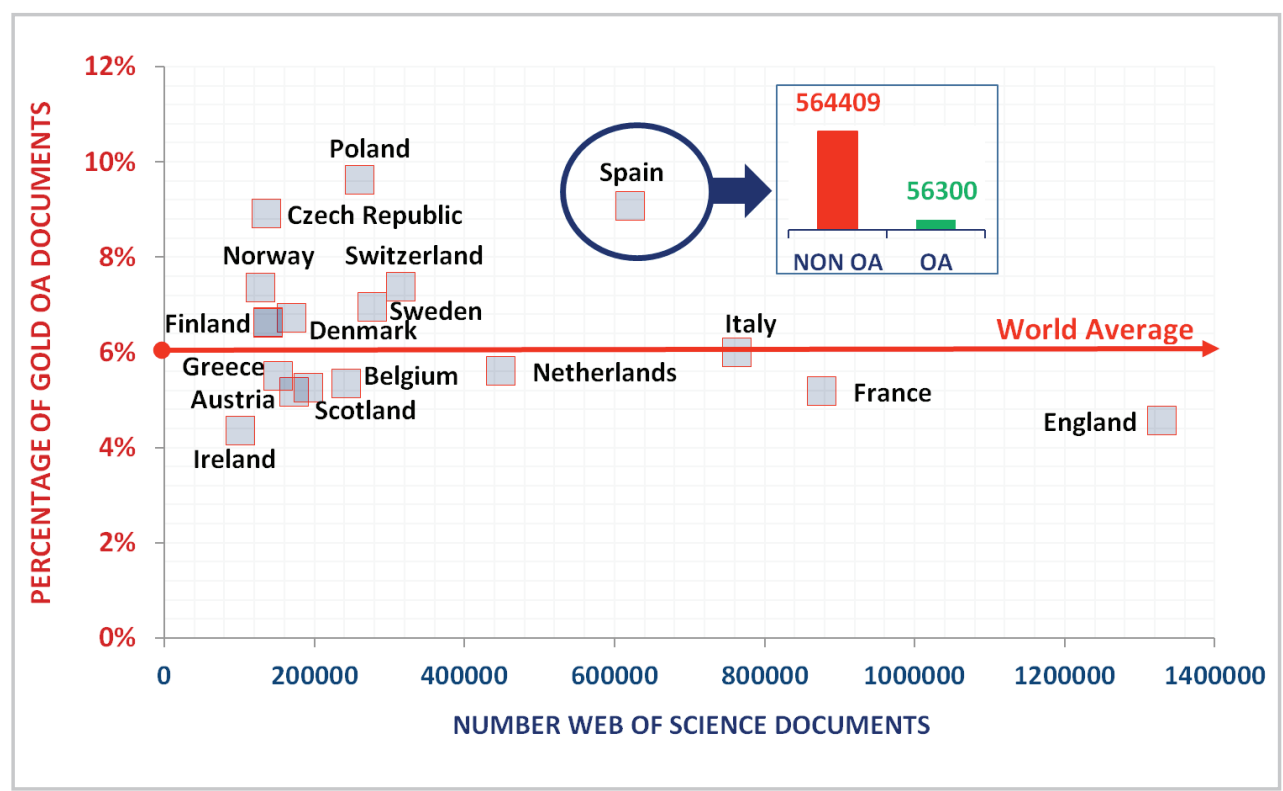

Figure 2. Share of papers published in Open Access journals indexed in the Web of Science for 17 European countries in the 2005-2014 time period

ropean country, followed by The Netherlands. If ranked according to its gold OA output, it is second, with only Poland ahead of Spain with nearly $10 \%$ of its whole research output published in OA journals. On the other hand, we observe how countries such as England, France, or The Netherlands show values below the world's $6 \%$ average of papers published in OA journals.

If we take a look at the research output of gold OA papers by year and by areas, we observe an increasing trend in all fields (table 1). Arts \& Humanities is the area with the highest share of papers published in OA journals (28\%); followed by Social Sciences (14\%); and Clinical, Pre-clinical \& Health $(10 \%)$. On the other end we find that the areas of Engineering \& Technology (4\%), Physical Sciences (5\%), and Life Sciences (9\%) are the ones with the lowest shares of gold OA papers. While the relative growth of gold OA literature is quite stable in these three areas over time, we observe more noticeable fluctuations in other areas such as Arts \& Humanities, which increased by 12 points in its share of gold OA papers from 2006 to 2007. Much more moderate are the fluctuations in Clinical, Pre-clinical \& Health, and Social Sciences areas where the greatest rise is three points in both cases (in 2007, 2009 and, 2014 in the case of the former and in 2007 for the latter).

\subsection{Impact and collaboration in OA output}

In regard to the scientific impact of gold OA literature, we observe that it systematically shows lower values for the time period analyzed than for the whole share. Table 2 compares gold OA versus the overall output of Spain during the

Table 1. Total number and share of papers authored by Spanish institutions published in Open Access journals indexed in the Web of Science by scientific area during the $2005-2014$ period

\begin{tabular}{|c|c|c|c|c|c|c|c|c|c|c|c|}
\hline & 2005 & 2006 & 2007 & 2008 & 2009 & 2010 & 2011 & 2012 & 2013 & 2014 & Total \\
\hline \multicolumn{12}{|l|}{ Arts \& Humanities } \\
\hline No. OA documents & 132 & 137 & 334 & 474 & 667 & 685 & 811 & 750 & 998 & 784 & 5,772 \\
\hline$\%$ OA documents & 16 & 16 & 28 & 25 & 28 & 30 & 32 & 28 & 32 & 30 & 28 \\
\hline \multicolumn{12}{|c|}{ Clinical, Pre-clinical \& Health } \\
\hline No. OA documents & 614 & 894 & 1,446 & 1,674 & 2,367 & 2,016 & 2,225 & 2,492 & 2,716 & 3,163 & 19,607 \\
\hline$\%$ OA documents & 5 & 6 & 9 & 9 & 12 & 10 & 10 & 11 & 11 & 14 & 10 \\
\hline \multicolumn{12}{|c|}{ Engineering \& Technology } \\
\hline No. OA documents & 148 & 106 & 188 & 287 & 459 & 616 & 648 & 900 & 943 & 983 & 5,278 \\
\hline$\%$ OA documents & 2 & 1 & 2 & 2 & 3 & 4 & 4 & 6 & 6 & 7 & 4 \\
\hline \multicolumn{12}{|l|}{ Life sciences } \\
\hline No. OA documents & 598 & 867 & 1,149 & 1,456 & 1,690 & 1,977 & 2,539 & 3,106 & 3,467 & 3,845 & 20,694 \\
\hline$\%$ OA documents & 4 & 5 & 6 & 6 & 7 & 8 & 9 & 11 & 12 & 14 & 9 \\
\hline \multicolumn{12}{|l|}{ Physical sciences } \\
\hline No. OA documents & 254 & 356 & 467 & 585 & 835 & 1,068 & 1,247 & 1,533 & 1,652 & 1,747 & 9,744 \\
\hline$\%$ OA documents & 2 & 2 & 3 & 3 & 5 & 6 & 6 & 7 & 8 & 8 & 5 \\
\hline \multicolumn{12}{|l|}{ Social sciences } \\
\hline No. OA documents & 208 & 259 & 450 & 708 & 710 & 849 & 1,040 & 989 & 1,050 & 1,059 & 7,322 \\
\hline$\%$ OA documents & 10 & 10 & 13 & 14 & 14 & 14 & 15 & 14 & 14 & 15 & 14 \\
\hline
\end{tabular}




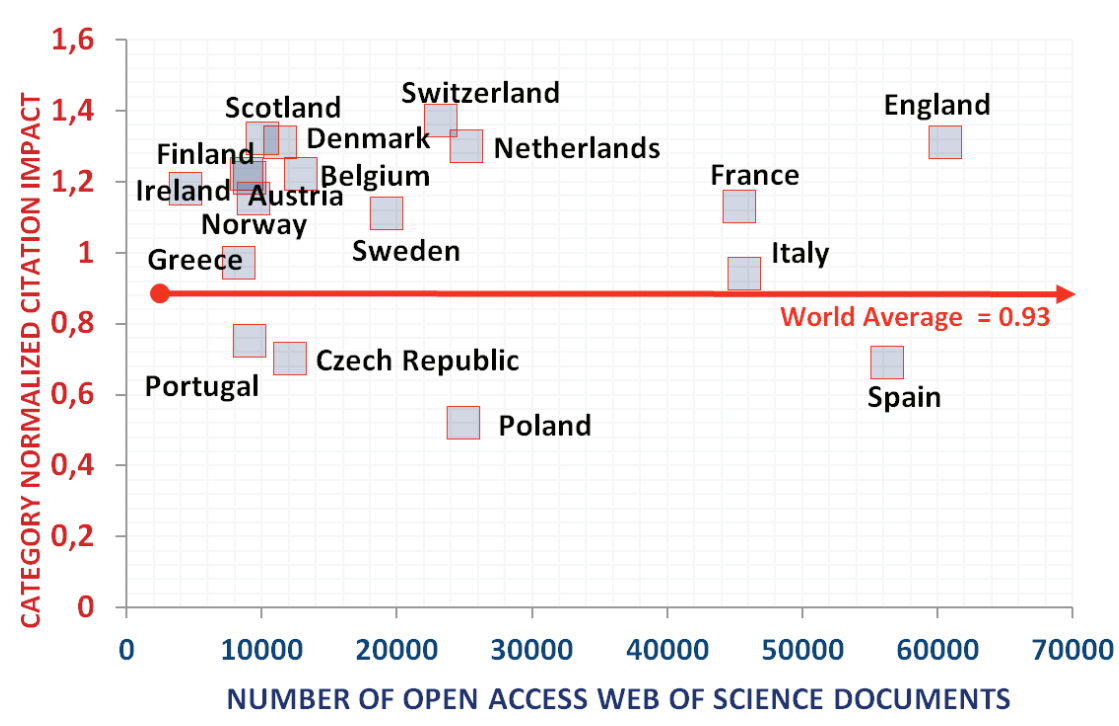

\begin{tabular}{|c|c|c|}
\hline \multicolumn{3}{|c|}{ Category Normalized Citation Impact } \\
\hline Country & General & OA \\
\hline AUSTRIA & 1,37 & 1,22 \\
\hline BELGIUM & 1,54 & 1,22 \\
\hline CZECH REPUBLIC & 1,13 & 0,70 \\
\hline DENMARK & 1,60 & 1,31 \\
\hline ENGLAND & 1,40 & 1,31 \\
\hline FINLAND & 1,30 & 1,21 \\
\hline FRANCE & 1,27 & 1,13 \\
\hline GREECE & 1,06 & 0,97 \\
\hline RELAND & 1,21 & 1,18 \\
\hline TALY & 1,23 & 0,94 \\
\hline NETHERLANDS & 1,54 & 1,30 \\
\hline NORWAY & 1,39 & 1,15 \\
\hline POLAND & 0,91 & 0,52 \\
\hline PORTUGAL & 1,11 & 0,75 \\
\hline SCOTLAND & 1,41 & 1,32 \\
\hline SPAIN & 1,15 & 0,69 \\
\hline SWEDEN & 1,39 & 1,11 \\
\hline SWITZERLAND & 1,63 & 1,37 \\
\hline
\end{tabular}

Figure 3. Category Normalized Citation Impact of gold Open Access publications indexed in the Web of Science compared with the overall output of 17 European countries in the 2005-2014 period

2005-2014 period. Analyzing the Category Normalized Citation Impact by year for both groups we observe that gold OA literature underperforms every year with values lower than the world average and 0.5 points behind the Spanish overall output. Although worldwide the Category Normalized Citation Impact of gold OA literature is also lower than the whole share, the gap is wider in the Spanish case. When focusing on the share of gold OA highly cited papers, again we see that these underperform when compared with the whole share. But, unlike differences observed according to the Category Normalized Citation Impact, they seem to slightly narrow the gap.

The opposite occurs regarding the share of internationally co-authored papers. Indeed, the share of international collaboration is higher in the case of gold OA papers than for the whole output. However, the trend in this case is also narrowing at a greater speed than in the case of highly cited papers. While values at the beginning of the period differ by about 10 points, since 2011 this gap has reduced to less than 5 points.

If we compare the impact indicators of Spanish gold OA output with other European countries, we observe that Spain shows one of the poorest performances (figure 3). Only Poland is behind Spain. Also, we must note the generally good performance of European gold OA research output. From the 17 countries analyzed, only Portugal, Czech Republic, Spain, and Poland show a lower Category Normalized Citation Impact than the world average.

In general, gold OA research output shows a lower Category Normalized Citation Impact than the overall research output of most of the countries analyzed. Big differences also can be found in the following countries: Belgium (1.54 for all output versus 1.22 for gold OA publications), Denmark (1.60 for all output versus 1.31 for gold OA publications), Italy (1.23 for all output versus 0.94 for gold OA publications) and Sweden (1.39 for all output versus 1.11) for gold OA publications).

In regard to the differences for impact and collaboration by areas (table 3 ), results are similar. In all fields the Category Normalized Citation Impact scores and the share of highly

Table 2. Scientific impact and international collaboration indicators for Spanish research output and for the share of Spanish gold OA output according to the Web of Science in the period 2005-2014.

\begin{tabular}{|c|c|c|c|c|c|c|}
\cline { 2 - 7 } \multicolumn{1}{c|}{} & \multicolumn{2}{c|}{$\begin{array}{c}\text { Category Normalized } \\
\text { Citation Impact }\end{array}$} & \multicolumn{2}{c|}{$\begin{array}{c}\text { \% documents } \\
\text { in top 10\% }\end{array}$} & \multicolumn{2}{c|}{$\begin{array}{c}\text { \% international } \\
\text { collaborations }\end{array}$} \\
\hline Year & General & OA & General & OA & General & OA \\
\hline 2005 & 1.08 & 0.57 & 10.81 & 5.06 & 23.14 & 32.85 \\
\hline 2006 & 1.08 & 0.68 & 11.26 & 4.73 & 22.60 & 33.98 \\
\hline 2007 & 1.08 & 0.59 & 11.30 & 5.02 & 22.81 & 32.53 \\
\hline 2008 & 1.09 & 0.66 & 11.02 & 5.92 & 25.24 & 33.58 \\
\hline 2009 & 1.11 & 0.61 & 11.41 & 5.06 & 23.67 & 33.79 \\
\hline 2010 & 1.17 & 0.72 & 11.41 & 6.42 & 28.51 & 36.26 \\
\hline 2011 & 1.17 & 0.78 & 11.50 & 6.79 & 32.48 & 38.23 \\
\hline 2012 & 1.27 & 0.73 & 11.15 & 6.32 & 34.55 & 39.35 \\
\hline 2013 & 1.22 & 0.74 & 10.58 & 5.92 & 37.05 & 41.43 \\
\hline 2014 & 1.17 & 0.67 & 8.34 & 3.85 & 41.00 & 45.39 \\
\hline
\end{tabular}

\begin{tabular}{|c|c|c|c|c|c|c|}
\cline { 2 - 7 } \multicolumn{1}{c|}{} & \multicolumn{7}{c|}{ Global data for the period 2005-2014 } \\
\hline Spain & 1.15 & 0.69 & 10.84 & 5.59 & 37.31 & 31.85 \\
\hline World & 0.98 & 0.72 & 8.84 & 5.77 & 15.42 & 19.16 \\
\hline
\end{tabular}


Table 3. Impact and international collaboration indicators for the Spanish research output and the gold Open Access output indexed in the Web of Science by scientific areas in the 2005-2014 period

\begin{tabular}{|l|c|c|c|c|c|c|}
\cline { 2 - 7 } \multicolumn{1}{c|}{} & \multicolumn{2}{c|}{$\begin{array}{c}\text { Category Normalized } \\
\text { Citation Impact }\end{array}$} & \multicolumn{2}{c|}{$\begin{array}{c}\text { \% documents } \\
\text { in top 10\% }\end{array}$} & \multicolumn{2}{c|}{$\begin{array}{c}\text { \% international } \\
\text { collaborations }\end{array}$} \\
\hline Research area & General & OA & General & OA & General & OA \\
\hline Arts \& Humanities & 0.97 & 0.30 & 5.25 & 1.40 & 8.40 & 3.97 \\
\hline Clinical, Pre-Clinical \& Health & 1.34 & 0.72 & 10.05 & 5.52 & 30.85 & 23.23 \\
\hline Engineering \& Technology & 1.15 & 0.55 & 10.33 & 2.90 & 29.89 & 30.01 \\
\hline Life Sciences & 1.27 & 0.85 & 9.77 & 7.63 & 39.69 & 43.04 \\
\hline Physical Sciences & 1.24 & 0.94 & 11.37 & 6.97 & 50.28 & 48.25 \\
\hline Social Sciences & 0.97 & 0.44 & 7.28 & 2.69 & 28.30 & 18.94 \\
\hline
\end{tabular}

the rest of the fields the general output shows higher international collaboration values than the gold OA subset.

\section{Discussion and concluding remarks}

This paper analyzes the research output of Spain in OA journals during the last decade based on publications indexed in the Web of Science. It specifically focuses on research output, citation impact, and international collaboration differences between gold

cited papers are higher for the whole research output when compared to papers published in OA journals; however, there are differences by area when focusing on international collaboration. The largest differences on Category Normalized Citation Impact can be observed in the fields of Arts \& Humanities (a difference of 0.67), followed by Clinical, Preclinical, \& Health (0.62) and Engineering \& Technology (0.6). In the case of highly cited papers, the largest differences are found in Engineering \& Technology (7.43 points of difference) while Life Sciences is the area with the lowest difference (2.14 points).

In the case of international collaborations, gold OA papers in the areas of Life Sciences have a larger share (3.35 points above the general output). There is a slight difference in the case of Engineering \& Technology ( 0.12 points above). In
OA and general output for papers authored by Spanish institutions. It also compares its results with other European countries and by scientific areas. Its aim is to analyze the current state of gold OA research in Spain and to characterize such research.

Spain has relatively high research output in OA journals when compared with the world average. The higher output is consistent for the entire period of analysis (figure 1). Clinical, Pre-clinical, \& Health, and Life Sciences represent nearly $60 \%$ of the whole share of gold OA output in Spain (table 1), while Arts \& Humanities and Social Sciences represent nearly $20 \%$. The rise of mega-journals such as PloS one or others may have contributed to the high rate of output in the biomedical and life sciences (Björk, 2015); and the large share of gold OA publications in the Arts \& Humanities and

Table 4. Ranking of the top 20 OA journals indexed in Web of Science with the highest number of Spanish publications during the study time period $2010-2014$

\begin{tabular}{|c|c|c|c|c|}
\hline Journal name & $\begin{array}{l}\text { Publisher } \\
\text { country }\end{array}$ & $\begin{array}{c}\text { Open Access } \\
\text { Web of Science docu- } \\
\text { ments } \\
\text { (Spain) }\end{array}$ & $\begin{array}{l}\text { Category Normalized } \\
\text { Citation Impact }\end{array}$ & $\begin{array}{c}\text { Journal } \\
\text { Impact Factor } \\
(2014)\end{array}$ \\
\hline PloS one & United States & 4,633 & 1.10 & 3.234 \\
\hline Revista española de cardiología & Spain & 2,066 & 0.79 & 3.792 \\
\hline Nefrología & Spain & 1,552 & 0.40 & 1.223 \\
\hline Gaceta sanitaria & Spain & 1,465 & 0.35 & 1.186 \\
\hline Revista española de enfermedades digestivas & Spain & 1,452 & 0.26 & 1.414 \\
\hline Nutrición hospitalaria & Spain & 1,206 & 0.35 & 1.040 \\
\hline Psicothema & Spain & 1,088 & 0.38 & 1.210 \\
\hline Optics express & United States & 1,058 & 1.59 & 3.488 \\
\hline Haematologica. The hematology journal & United Kingdom & 962 & 1.29 & $\mathrm{n} / \mathrm{a}$ \\
\hline Sensors & United States & 837 & 0.70 & 2.245 \\
\hline Arbor. Ciencia pensamiento y cultura & Spain & 740 & 0.20 & $\mathrm{n} / \mathrm{a}$ \\
\hline Medicina intensiva & Spain & 734 & 0.30 & 1.336 \\
\hline Anuario de estudios medievales & Spain & 694 & 0.16 & $\mathrm{n} / \mathrm{a}$ \\
\hline Spanish journal of agricultural research & Spain & 656 & 0.43 & 0.703 \\
\hline Anales de psicología & Spain & 569 & 0.25 & 0.504 \\
\hline Journal of investigational allergology and ... & Spain & 534 & 0.48 & 2.596 \\
\hline Revista española de salud pública & Spain & 520 & 0.26 & 0.693 \\
\hline Anales del sistema sanitario de Navarra & Spain & 510 & 0.14 & 0.436 \\
\hline New journal of physics & United Kingdom & 506 & 1.60 & 3.558 \\
\hline Nucleic acids research & United Kingdom & 485 & 1.53 & 9.112 \\
\hline
\end{tabular}


Social Sciences may be because the journals in these fields are often edited by public institutions such as universities or the Spanish National Research Council (CSIC), all of which are generally more inclined towards Open Access (Abadal; Rius-Alcaraz, 2008). In this sense, we must acknowledge the increasing coverage of Spanish journals in the Web of Science since 2007 in these areas (Osca-Lluch, 2012).

Hence, one could speculate that other factors, rather than the OA factor, affect the impact of these journals, for example the publisher type or the field of study. It is possible that in Biomedical and Life Sciences the OA publishers are big commercial enterprises while in the Social Sciences and Humanities, OA publishers are small institutional journals. In the case of Physical Sciences something different could be happening. Initiatives such as the Scoap3 partnership (Sponsoring Consortium for Open Access Publishing in Particle Physics), which intends to convert key journals in the field of Particle Physics into OA journals, may also bias the results in favor of gold $O A$.

http://scoap3.org

Further analysis by field would be desirable in order to understand if $\mathrm{OA}$ is the key factor affecting impact or if there are other important variables. Following this line of thought, the thematic profile of countries will also influence the overall impact of its gold OA output.

Although worldwide the impact of gold OA literature is lower than the whole share, the gap is wider in the Spanish case

In regard to the characteristics of this type of research output, we observe that in general there are low impact figures in all areas and in comparison with other countries (table 3 and figure 3). As mentioned before, there is a group of countries (Spain, Poland Czech Republic, and Ireland) where publications in OA journal have a lower impact, especially when compared with other countries such as England, Denmark, or Switzerland. The reasons behind such poor performance may be due to the national factor (most of these papers are published in national OA journals) as well as to the large share of gold OA papers in comparison to the rest of the countries (figure 2).

Such a hypothesis seems to be in line with the results shown by Ennas and Di-Guardo (2015). Indeed, as observed from table 4, there are two factors which explain the lower impact of gold OA in Spain. First, there is a concentration of Spanish journals publishing in the Spanish language (Nefrología, Gaceta sanitaria, Nutrición hospitalaria, etc.). Second, these journals all have a low Journal Impact Factor and are therefore considered a less attractive publication for researchers. These factors affect the Category Normalized Citation Impact indicators and lower the aggregated impact of Spanish publications in OA journals. This phenomenon is also observed in countries such as Poland and Portugal.

Collaboration differences between OA output and the ag- gregated production of countries are consistently higher during the analyzed period (table 2), but there seems to be biases depending on the area (table 3). However, differences do not seem to be too significant, hence further research is needed to investigate if international collaboration plays a role in OA publication patterns.

The results shown here work against those shown in other studies in which a certain citation advantage is observed for OA papers

In general, the results shown here work against those shown in other studies in which a certain citation advantage is observed for OA papers (i.e., Gargouri, et al., 2010), although they seem consistent with those described by Solomon, Laakso, and Björk (2013) who showed that subscription-based journals performed better than born OA journals or converted OA journals. The present paper is of a descriptive nature, offering a first approach towards understanding gold OA publishing in Spain. Also one must consider the already known limitations of any study using the Web of Science as a data source, such as language biases or field biases (Moed, 2005). Further analyses are still needed to deepen the understanding of the characteristics of OA journals and determine key variables that influence impact.

\section{References}

Abadal, Ernest (2015). "Gold or green: The debate on open access policies". Contributions to science, v. 10, n. 1, pp.89-93. http://dx.doi.org/10.2436/20.7010.01.192

Abadal, Ernest; Melero, Remedios; Rodrigues, Rosângela; Navas-Fernández, Miguel (2015). "Spanish scholarly journals in WoS and Scopus: The impact of open access". Journal of scholarly publishing, v. 47, n. 1, pp. 77-96.

http://eprints.rclis.org/28108

Abadal, Ernest; Rius-Alcaraz, Lluís (2008). “Revistas científicas de las universidades españolas: Acciones básicas para aumentar su difusión e impacto". Revista española de documentación científica, v. 31, n. 2, pp. 242-262.

http://dx.doi.org/10.3989/redc.2008.v31.i2.427

Agrawal, Anurag A. (2014). "Four more reasons to be skeptical of open-access publishing". Trends in plan science, $v$. 19, n. 3, pp. 133.

http://dx.doi.org/10.1016/j.tplants.2014.01.005

Alonso-Arévalo, Julio; Subirats, Inma; Martínez-Conde, María-Luisa (2008). Informe APEI sobre acceso abierto. ISBN: 9788469177259

http://eprints.rclis.org/12507/1/informeapeiaccesoabierto.pdf

Archambault, Éric; Amyot, Didier; Deschamps, Philippe; Nicol, Aurore; Provencher, Françoise; Rebout, Lise; Roberge, Guillaume (2014). Proportion of open access papers published in peer-reviewed journals at the European and world levels: 1996-2013. Report to the European Commission. http://www.science-metrix.com/files/science-metrix/publications/d_1.8_ sm_ec_dg-rtd_proportion_oa_1996-2013_v11p.pdf 
Beall, Jeffrey (2015). "Predatory journals and the breakdown of research cultures". Information development, v. 31, n. 5, pp. 473-476.

http://dx.doi.org/10.1177/0266666915601421

Björk, Bo-Christer (2015). "Have the 'mega-journals' reached the limits to growth?". PeerJ, v. 3, e981.

http://dx.doi.org/10.7717/peerj.981

Björk, Bo-Christer; Roos, Annikki; Lauri, Mari (2009). "Scientific journal publishing: yearly volume and open access availability". Information research, v. 14, n. 1, Paper 391. http://www.informationr.net/ir/14-1/paper391.htm/

Björk, Bo-Christer; Solomon, David (2015). “Article processing charges in OA journals: relationship between price and quality". Scientometrics, v. 103, n. 2, pp. 373-385.

http://www.openaccesspublishing.org/oa12/D01\%20 10.1007s11192-015-1556-z.pdf

http://dx.doi.org/10.1007/s11192-015-1556-z

Ennas, Gianfranco; Di-Guardo, Maria-Chiara (2015). “Features of top-rated gold open access journals: An analysis of the Scopus database". Journal of informetrics, v. 9, n. 1, pp. 79-89.

http://dx.doi.org/10.1016/j.joi.2014.11.007

Gargouri, Yassine; Hajjem, Chawki; Larivière, Vincent; Gingras, Yves; Carr, Les; Brody, Tim; Harnad, Stevan (2010). "Self-selected or mandated, open access increases citation impact for higher quality research". PloS one, v. 5, n. 10, e13636.

http://arxiv.org/pdf/1001.0361.pdf

http://dx.doi.org/10.1371/journal.pone.0013636

Ginsparg, Paul (1994). "First steps towards electronic research communication". Computers in physics, v. 8, n. 4, pp. 390-396.

http://dx.doi.org/10.1063/1.4823313

Harnad, Stevan (2007). "The green road to open access: A leveraged transition". In: Gacs, Anna. The culture of periodicals from the perspective of the electronic age. L'Harmattan, pp. 99-105.

http://eprints.soton.ac.uk/265753

Harnad, Stevan; Brody, Tim; Vallières, François; Carr, Les; Hitchcock, Steve; Gingras, Yves; Oppenheim, Charles; Stamerjohanns, Heinrich; Hilf, Eberhard (2004). "The access/impact problem and the green and gold roads to open access". Serials review, v. 30, n. 4, pp. 310-314. http://eprints.soton.ac.uk/259939

http://dx.doi.org/10.1016/j.serrev.2004.09.013

Melero, Remedios; Abadal, Ernest; Abad; Francisca; Rodríguez-Gairín, Josep-Manuel (2009). "The situation of open access institutional repositories in Spain: 2009 report". Information research, v. 14, n. 4, paper 415.

http://www.informationr.net/ir/14-4/paper415.htm/

Moed, Henk F. (2005). Citation analysis in research evaluation. Springer. ISBN: 9781402037139

http://dx.doi.org/10.1007/1-4020-3714-7

Odlyzko, Andrew M. (1995). "Tragic loss or good riddance? The impending demise of traditional scholarly journals". International journal of human-computer studies, v. 42, n. 1 , pp. 71-122.

http://dx.doi.org/10.1006/ijhc.1995.1004

Osca-Lluch, Julia (2012). “Aspectos regionales de las revistas españolas de ciencias socials: Calidad y visibilidad internacional". Biblio 3W: Revista bibliográfica de geografía y ciencias sociales, v. 17, n. 998.

http://goo.gl/30ThZf

Solomon, David; Laakso, Mikael; Björk, Bo-Christer (2013). "A longitudinal comparison of citation rates and growth among open access journals". Journal of informetrics, v. 7, n. 3, pp. 642-650.

http://dx.doi.org/10.1016/j.joi.2013.03.008

Swan, Alma (2010). "The open access citation advantage: Studies and results to date".

http://eprints.soton.ac.uk/268516

Torres-Salinas, Daniel; Orduña-Malea, Enrique (2014). "Ruta dorada del open access en Web of Science". Anuario ThinkEPI, v. 8, pp. 211-214.

Van-Leeuwen, Thed N.; Tatum, Clifford; Wouters, Paul (2015). "Open access publishing and citation impact - An international study". In: Salah, A. A.; Tonta, Yapar; AkdagSalah, A. A.; Sugimoto, Cassidy; Al, U (eds). Proceedings of ISSI 2015 Istanbul: $15^{\text {th }}$ Interl Society of Scientometrics and Informetrics Conf, 2015, pp. 1130-1141.

http://www.issi2015.org/files/downloads/all-papers/1130.pdf

Villalón-Panzano, Javier; Aguillo, Isidro F. (1998). "Revistas electrónicas en ciencias sociales y humanidades". Revista española de documentación científica, v. 21, n. 3, pp. 303316.

http://dx.doi.org/10.3989/redc.1998.v21.i3.358

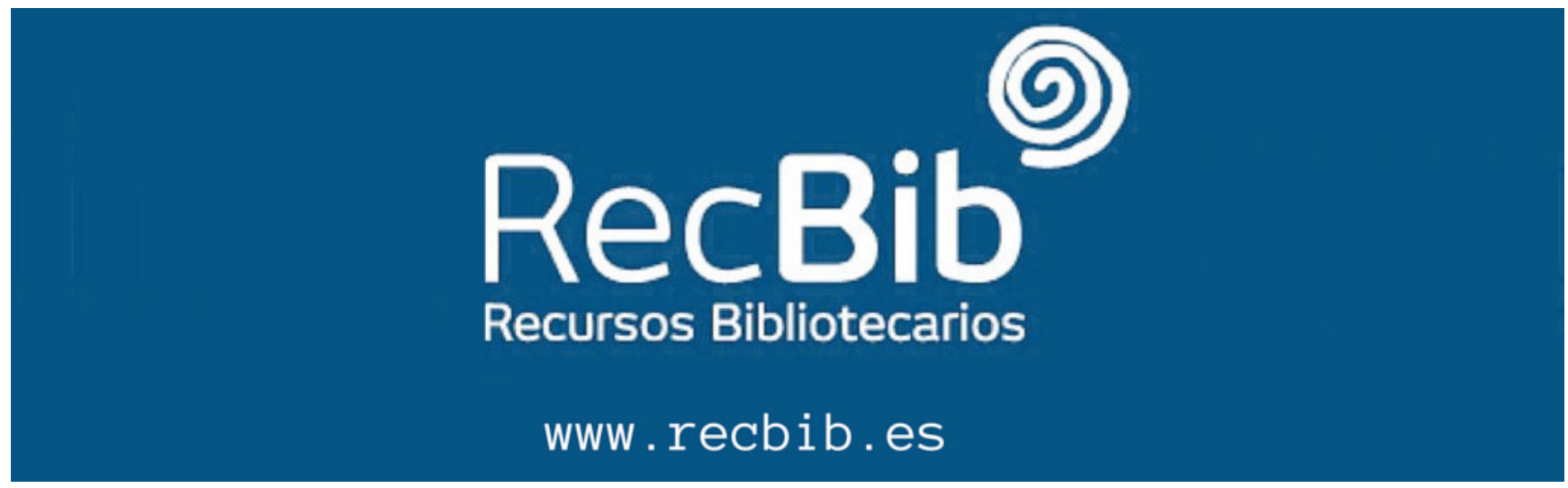

